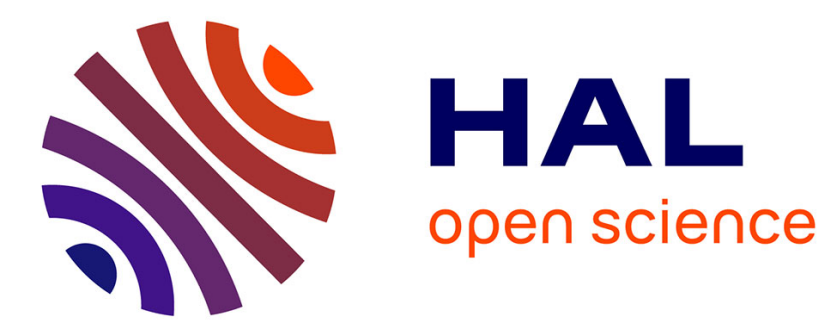

\title{
Methodological proposal for the inventory and assessment of geoarchaeosites: Application to the middle Eure valley (Paris Basin, France)
}

\author{
Théophile Piau, Francois Betard, Fabienne Dugast
}

\section{- To cite this version:}

Théophile Piau, Francois Betard, Fabienne Dugast. Methodological proposal for the inventory and assessment of geoarchaeosites: Application to the middle Eure valley (Paris Basin, France). European Geosciences Union General Assembly, Apr 2021, Vienne (virtual), Austria. 2021. hal-03183618

\section{HAL Id: hal-03183618 \\ https://hal.sorbonne-universite.fr/hal-03183618}

Submitted on 2 May 2021

HAL is a multi-disciplinary open access archive for the deposit and dissemination of scientific research documents, whether they are published or not. The documents may come from teaching and research institutions in France or abroad, or from public or private research centers.
L'archive ouverte pluridisciplinaire HAL, est destinée au dépôt et à la diffusion de documents scientifiques de niveau recherche, publiés ou non, émanant des établissements d'enseignement et de recherche français ou étrangers, des laboratoires publics ou privés. 


\section{Methodological proposal for the inventory and assessment of geoarchaeosites:}

Application to the middle Eure valley (Paris Basin, France)

Théophile Piau ${ }^{1}$, François Bétard ${ }^{1} \&$ Fabienne Dugast ${ }^{2}$

${ }_{1}^{1}$ Université de Paris, UMR 8586 Prodig, theophilepiau@yahoo.fr ; ${ }^{2}$ UMR 8167 Orient \& Méditerranée, Paris (France)

\section{Exemple of application to the middle Eure valley: first results}

$>$ sites of particular relevance for the understanding of past human-environment interactions

$>$ geomorphological and archaeological components have the same level of importance

\section{Methodology for the inventory and assessment of geoarchaeosites}

Two main stages

in our proposed methodology:

(1) The inventory

= identification and selection

of potential geoarchaeosites

Which should be both representative - of the regional geomorphological setting (spatial axis)

- of the archaeological periods (temporal axis).

(2) The assessment

= divided into three main steps

from the assessment of the scientific

value to that of the potential use

(see details in the workflow)
- A first selection of $\mathbf{2 0}$ "disconnected geoarchaeosites"

- With contrasted scientific values

- Which illustrate past human-environment interactions

- At various spatio-temporal scales
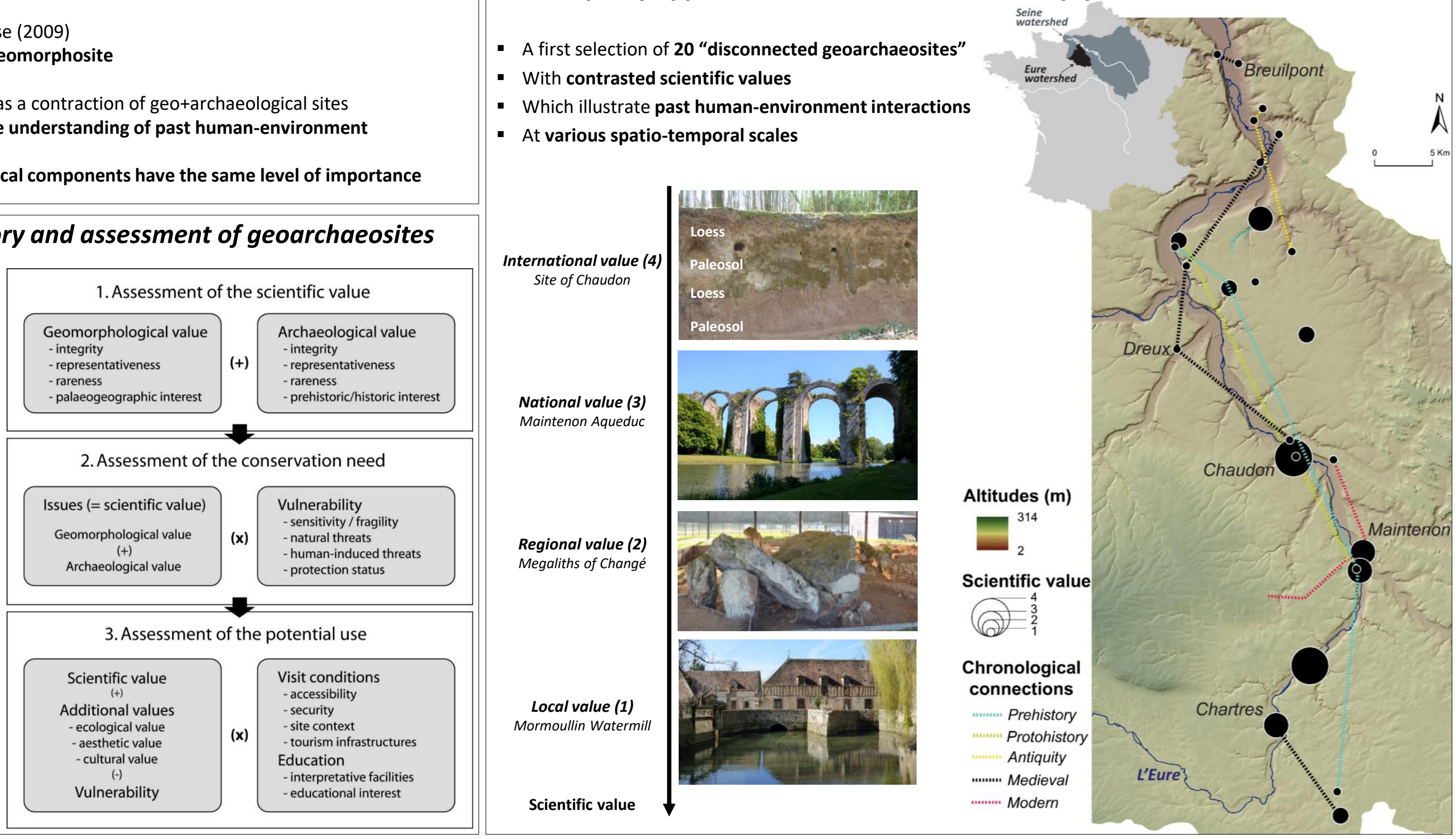